\title{
Seed Yield and Seed Quality of Some Soybean Genotypes as Influenced by Planting Date \\ Morsy, A. R. ${ }^{1}$ : Eman N. M. Mohamed ${ }^{2}$ and Th. M. Abou-Sin ${ }^{1}$ \\ 1- National food legume Res. Prog, Field Crops Res. Inst., ARC, Giza, Egypt ${ }^{1}$ \\ ${ }^{2-}$ Seed Technology Res. Section, Field Crops Res. Inst., ARC, Giza, Egypt ${ }^{2}$
}

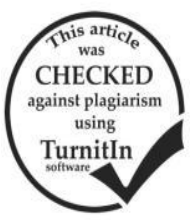

\section{ABSTRACT}

This study was conducted at Sakha Agricultural Research Station, kafr El_Shiekh, Egypt during 2013 and 2014 growing summer season to determine the effects of three planting dates on seed yield and seed quality of ten soybean genotypes. The planting dates starting from mid-May at 15 days intervals. The soybean genotypes included Giza 22, Giza 35, Giza 111, and Crawford (four commercial soybean cultivars), $\mathrm{H} \mathrm{30}, \mathrm{H} \mathrm{32}, \mathrm{H}_{2} \mathrm{~L}_{12}$, and DR101(promising lines) and two introductions (Toano and Holladay). The obtained results of the combined data showed that delaying from mid-May to mid-June significantly decreased numbers of days to flowering and maturity from 40.4 and 133.91 days, respectively to 34.3 and 122.2 days, and shortened the reproductive growth stage from 93.9 to 88.0 days, along with reducing weight of 100 seeds from 15.92 to $12.39 \mathrm{~g}$, and seed yield per feddan from 1.613 to $1.053 \mathrm{ton} / \mathrm{fed}^{-1}$. On contrary, seed protein content and seed germination were increased from 33.23 and $69.5 \%$ to 39.09 and $89.67 \%$, respectively, while oil content was decreased by delaying planting from 23.06 to $19.18 \%$. The soybean genotypes varied in all studied traits, that DR 101 was the latest in flowering and maturity (51.3 and 150.3 days, respectively) and produced the highest 100 -seed weight $(17.2 \mathrm{~g})$, while $\mathrm{H} 30$ was the earliest in maturity (115.00 days) and the lowest in 100-seed weight $(12.14 \mathrm{~g})$. The commercial cultivar Giza 111 produced the highest seed yield (1.625t/fed.). Data showed also that Toano was the best in seed germination over all planting dates with $90.22 \%$ as an average, whereas $\mathrm{H} 32$ was the bad in seed germination (60.22\%). It could be concluded that, Giza 111, Toano and DR 101 could produce acceptable seeds with more than $80 \%$ germination when planted during the first half of June, while the earlier genotypes H30, H32, and Giza 35 must be planted around mid-June to produce seeds with acceptable viability.

Keywords: Soybean, planting dates, seed yield, seed quality, oil and protein content.

\section{INTRODUCTION}

Soybean (Glycine max L. Merr) is usually referred to as a short day plant; however, there is a broad range of soybean responses to photoperiod due to the genetic constitution of grown cultivars. The day length is an important determinate for flowering and maturity dates and its greatly affected by planting date. Day length strongly influences the morphology of the soybean plant, and its agronomic characters including seed yield. Soybean seed yield is determined by the interaction of the genetic yield potential and the environmental conditions.

Optimum planting dates are usually those that result in prompt emergence and longest vegetative period for adapted cultivars. The reproductive period is often longer with earlier planting dates and shorter with later ones than those of the optimal period (Garcia, 1994). Compared to earlier planting, delayed planting date decreased yield potential. The yield loss from delayed planting is commonly due to decreases of vegetative and reproductive growth stages (Pedersen and Lauer, 2003; and 2004 Bastidas et al., 2008; De Bruin and Pedersen, 2008; and Salmeróna et al., 2016). Yield reduction in late-planted, soybeans has been attributed to the lack of sufficient vegetative and reproductive growth (Ball et al., 2000 and Heatherly, 2005). Seed yield is greater from earlier planted soybeans due to longer duration of vegetative and reproductive growth stages (Chen and Wiatrak, 2010). Additionally, soybean seed yield is correlated with length of flowering, pod set (Egli and Bruening, 2000), and seed filling periods (Andrade, 1995). Earlier planting can potentially intercept greater amounts of solar radiation due to a longer growing season.

Early planting increased economic return ha ${ }^{1}$ (Jason and Palle, 2008, David et al., 2016; and Salmeróna et al., 2016), and provide higher 100-seed weight, and higher seed yields than late planting (Kandil et al., 2013; and Scott et al., 2013). Soybean cultivars are different in their response to the day length, which is the primary environmental variable triggering change in length of vegetative period (Valéria et al., 2002; and Jeffery et al., 1996).

The important variable to consider when identifying the optimum planting date is the maturity group of the soybean cultivars (Salmeron et al., 2014; and Salmeróna et al., 2016). Chen and Wiatrak (2010) found that the yield maximizing planting date was midMay for MG IV and early-May to mid-June for MG V in South Carolina. Salmeron et al. (2014) recently analyzed two years of data from 10 locations in the Mid-South to determine the relationship between MGs and planting date. He found that, when soybeans were planted at the late planting date (May through June), yields decreased by $7 \%$ for MG III, $12 \%$ for MG IV, $18 \% \mathrm{MG} \mathrm{V}$, and $11 \%$ for MG VI relative to the early planting dates (March through April). Generally, soybean yields were maximized for MG III through V (i.e., earlier MGs) when planted in April and yield were maximized for MGs V through VII (later MGs) in May and June for the southern United States (Egli and Cornelius, 2009).

Planting date not only influences the seed yield, but also the quality of soybean seeds such as germination, oil, and protein contents. Germination of soybean seed is influenced by the cultivars and their sowing date. The late sowing date produced seeds with high germination and vigor for all cultivars (Amir et al., 2007; Rahman et al, 2013). Planting dates change the seed composition by changing the content of oil (Muhammad et al., 2009), and protein (Kumar et al., 2006). Tremblay et al., 2006; Kumar et al., 2006; and El-Borai et al., 2006 found that oil content decreased with delayed planting dates and temperature is thought to be related with this response. Delaying planting date usually results in higher seed protein content (kane et 
al., 1997), although Bastidas et al. (2008) reported an inconsistent effect of planting date on protein content. Oil and protein contents can change according to cultivar (Bastidas et al., 2008), but environmental conditions seem to have the greatest effect.

In Egypt soybean is planted over a relatively longer period of time extending from mid-April to midJune depending on the time of cleaning the field from the preceding crop El-Borai et al., (2006). Consequently, the objective of this study was to evaluate the influence of different planting dates on seed yield; germination and seed quality of ten soybean genotypes.

\section{MATERIALS AND METHODS}

A field experiment was conducted during 2013 and 2014 summer seasons at the experimental farm of Sakha Agricultural Research Station, kafr El_Shiekh, Egypt, to study the influence of three planting dates (started from mid-May with 15 days intervals) on seed yield and seed quality of ten soybean genotypes. The studied soybean genotypes were Giza 22, Giza 35, Giza 111, and Crawford (commercial cultivars), H 30, H 32, H2 L12, and DR101(promising lines) beside two introductions (Toano, and Holladay). The first eight genotypes belong to indeterminate growth type of soybean varieties, while, the last two genotypes (introductions) belong to determinate growth type.

These soybean genotypes represent different maturity groups according to the American classification, i.e. Giza 35, and H30 (Maturity group III), Giza 22, Giza 111, Crawford, H32, and H2 L12 (Maturity group IV), and the others are Maturity group V. The experimental design was split plot with three replications. The planting dates were allotted to main plots and genotypes to sub plots. Each sub plot consisted of six ridges, $4 \mathrm{~m}$ long and $0.70 \mathrm{~m}$ apart. Seeds of all genotypes were inoculated with specific rhizobia before planting, and the other agricultural practices were applied as recommended. At harvest, data were recorded on number of days from planting to $50 \%$ flowering (flowering date), number of days to $95 \%$ maturity (maturity date), while reproductive growth stage was calculated as a difference between maturity date and flowering date (maturity date -flowering date), for each genotype in each planting date. Seed yield was determined from the central four ridges of each plot in kilograms and transformed to ton/fed. Also, a seed sample of $50 \mathrm{gm}$ from each sub-plot was taken to determine 100-seed weight, standard germination, oil content and protein content. All seed properties were carried out at Sakha Seed Technology Research Section as follow:

\section{Laboratory experiment:}

Standard germination test was carried out according to the international rules of testing (ISTA, 1999). The germination percentage was conducted on four replicates of 50 seeds for each seed sample using folded paper towels at $29^{\circ} \mathrm{C}$ and germination counts for normal seedlings were done after seven days. The electrical conductivity (EC) of leaches from four replicates of 50 seeds weighted and soaked in $250 \mathrm{ml}$ of distilled water for $24 \mathrm{~h}$, was measured in $\mu$-mhos using conductivity meter, according to the international rules (ISTA, 1999). Seed protein and oil contents (\%) were determined according to procedures outlined in AOAC, 1990.

\section{Statistical analysis:}

All data collected were subjected to statistical analysis of variance as described by Snedecor and Cochran (1967). The mean values were compared according to Duncan's Multiple Range Test (Duncan, 1955).

\section{RESULTS AND DISCUSSION}

Data presented in Table 1 show clearly that planting date significantly affected all studied traits. Delaying planting date from mid-May to mid-June significantly shortened the maturity duration as well as the vegetative and reproductive growth stages.

Flowering and maturity dates along with the length of reproductive growth stage were significantly decreased due to delaying soybean planting date over 2013 and 2014 seasons. The highest mean numbers of days to flowering and maturity (40.4 and 133.9 days) were recorded in the early planting date (May, 15),comparing with 34.3 and 122.2 days for the late planting date (June,15) over both seasons (combined data). Also, the length of reproductive growth stage was significantly decreased from 93.9 days in the early planting date to 88.0 days in the late planting date over both seasons (Table, 1).

Concerning studied soybean genotypes, combined data in table 1 showed that, DR 101 was the latest genotype in flowering and maturity over all planting dates and recorded 51.3 and 150.3 day, respectively with the longest reproductive growth stage (99.3 days) over both seasons. Although, Giza 35 was the earliest in flowering (28 days), H30 was the earliest genotype in maturity (115.0 days) beside the shortest reproductive growth stage ( 84.5 days) over seasons. It was noticed also that Holladay and Toano followed DR 101 in flowering and maturity dates with slight difference, while the values of reproductive growth stage of DR 101, Holladay, Toano, and Giza 111 (99.3, 95.3, 93.0 and 91.4 days) were not significantly different over both seasons.

Data in Table 1 showed that, 100-seed weight was influenced by planting date, and significantly affected in the combined analysis. The heaviest 100 seed- weight $(15.52 \mathrm{~g})$ was produced in the early planting date (May, 15) compared with $12.39 \mathrm{~g}$ at the late planting date (June, 15) in the combined analysis. Studied soybean genotypes were significantly different in 100-seed weight over both seasons, whereas, DR 101 genotype had the highest 100 -seed weight $(17.20 \mathrm{~g})$ over all planting dates in the combined analysis, followed by Toano and Holladay (16.02 and $15.99 \mathrm{~g}$, respectively) in the combined analysis, while $\mathrm{H} 30$ and $\mathrm{H} 32$ recorded the lowest values of 100 seed- weight (12.68 and $12.77 \mathrm{~g}$, respectively) in the combined analysis. 
Table 1. Mean performance of studied soybean genotypes for some agronomic characters at different planting dates.

\begin{tabular}{|c|c|c|c|c|c|c|c|c|c|c|c|c|c|c|c|}
\hline \multirow{2}{*}{$\begin{array}{l}\text { Characters } \\
\text { Treatment } \\
\text { planting } \\
\text { date (D) }\end{array}$} & \multicolumn{3}{|c|}{$\begin{array}{c}\text { Days to flowering } \\
\text { (no.) }\end{array}$} & \multicolumn{3}{|c|}{$\begin{array}{c}\text { Days to maturity } \\
\text { (no.) }\end{array}$} & \multicolumn{3}{|c|}{$\begin{array}{c}\text { Reproductive } \\
\text { growth stage (days) }\end{array}$} & \multicolumn{3}{|c|}{$\begin{array}{c}\text { 100-seed weight } \\
(\mathrm{gm})\end{array}$} & \multicolumn{3}{|c|}{ Seed yield ton fed $^{-1}$} \\
\hline & 2013 & 2014 & Comb. & 2013 & 2014 & Comb. & 2013 & 2014 & Comb. & 2013 & 2014 & Comb. & 2013 & 2014 & Comb. \\
\hline D1 & 39.9 & 40.1 & 40.4 & 133.2 & 134.6 & 133.9 & 93.5 & 94.5 & 93.9 & 14.37 & 17.22 & 15.92 & 1.630 & 1.595 & 1.613 \\
\hline D2 & 37.1 & & 36.4 & & & & 93.3 & & & & & & & & 1.363 \\
\hline D3 & 33.9 & 34.3 & 34.3 & 121.5 & 122.9 & 122.2 & 87.4 & 88 & 88.0 & 10.46 & 13.92 & 12.39 & 0.962 & 1.117 & 1.053 \\
\hline L.S.D 0.01 & \multicolumn{15}{|c|}{ Genotypes } \\
\hline Н 30 & 30.2 & 30.8 & 30.5 & 114.2 & & & 84.0 & 84.9 & 84.5 & 11.01 & & & & & 1.256 \\
\hline Н 32 & 31.8 & 31.5 & 31.6 & 124.3 & 121.5 & 123 & 92.6 & & & 11.68 & 13.67 & & & & 153 \\
\hline H2 L12 & 34.0 & 33.8 & 33.9 & 124.3 & 122.0 & 123.2 & 90.3 & 88 & 89.4 & 11.23 & 13.96 & 13.10 & 1.622 & & 1.558 \\
\hline Giza 2 & 31.0 & 30.8 & 30.9 & 19.3 & 122.3 & 120.9 & 89.0 & 91.5 & 90.3 & 11.33 & 14.63 & 13.15 & 1.402 & 1.426 & 1.414 \\
\hline Giza & .0 & & 2 & 7.3 & 116.4 & 116.9 & 89.3 & & 88 & 12.64 & & & & & .349 \\
\hline Giza & & & & 127.1 & 128.9 & 128.0 & 93.4 & & 94 & .98 & & & & & 625 \\
\hline Cra & & & 30 & 2.0 & 124.6 & 3.3 & 89.0 & 93 & 91 & 11.82 & 14.66 & & & & 229 \\
\hline Toa & & & 47.7 & 40.6 & 14 & & 92.6 & 93 & 93 & 14.84 & 87 & & & & 273 \\
\hline & & & & 5.3 & 145 & & 94.7 & 96 & 95 & 14.12 & 17.47 & .79 & 1.270 & 1.3 & 1.306 \\
\hline DR 10 & & & & 149.0 & 151.6 & & 97.7 & 100 & 99.3 & 15.74 & 18.65 & 17.20 & 1.292 & 1.2 & 1.267 \\
\hline L.S.D 0.01 & 1.068 & 1.076 & 0.159 & 3.78 & 4.418 & 2.630 & 3.680 & 4.485 & 2.633 & 0.569 & 0.406 & 0.344 & 0.143 & 0.119 & 0.129 \\
\hline
\end{tabular}

Data showed that, seed yield per fed. was significantly influenced by planting date in the combined analysis, as presented in Table 1. Over all studied soybean genotypes, the highest seed yield was obtained from plants seeded on middle May. Seed yield was declined rapidly when planting date was delayed beyond the middle of June. The highest of seed yield (1.613 ton $\mathrm{fed}^{-1}$ ) was obtained from early planting date (May, 15) compared with 1.036t/fed. at the late planting date over 2013 and 2014 seasons (combined analysis). The studied soybean genotypes differed in their seed yield per feddan that, Giza 111 cultivar had the highest seed yield (1.629 ton fed $\left.^{-1}\right)$ over the different planting dates in the combined analysis, followed by H2 L12 and Giza 22 (1.558 and 1.414 ton $\mathrm{fed}^{-1}$, respectively) in the combined analysis, while $\mathrm{H} 32$ had the lowest of seed yield (1.153 ton $\left.\mathrm{fed}^{-1}\right)$, over both seasons in the combined analysis.

The length of soybean reproductive growth stage was significantly affected by the interaction of planting dates and soybean genotypes as shown in table 2 . The length of the reproductive growth stage of Giza 111 and H32 was the highest (96.8 and 94.2 days, respectively) in the medium planting date (June, 1) over the two growing seasons (combined data). Also, the reproductive growth stages of $\mathrm{H} 30, \mathrm{H} 2 \mathrm{~L} 12$, Giza 22, Toano, Holladay and DR 101 were not significantly different among the early and medium planting dates (May, 15 and June,1) over both seasons. In general, the reproductive growth stage of most studied soybean genotypes were significantly shorter in the late planting date (June, 15) over 2013 and 2014 seasons (combined data).

The seed yield per feddan of all soybean genotypes was significantly higher in the early planting date (May, 15), and significantly decreased with delaying planting date to the onset of June over both seasons (table 2).

The previous results support the hypothesis that soybean yield would increase at the early planting date, which was mainly driven by increased 100 -seed weight. Early planting dates allowed the vegetative and reproductive periods to start earlier, and to be longer than late planting dates which contribute to increased seed yields according to (Wilcox and Frankenberger, 1987; Cooper, 2003; De Bruin and Pedersen, 2008; Elgi and Cornelius, 2009, and Kandil et al., 2013); they add also that, the point of rapid decline in soybean yield begins on May $30^{\text {th }}$ in the Midwest.

The percentage of seed germination showed highly significant response to planting date and differed among soybean genotypes. The percentage of seed germination over all planting dates and soybean genotypes was greater in 2013 season than 2014. Delaying planting date from mid-May to mid-June significantly increased the percentage of seed germination over all studied soybean genotypes from 69.50 to $89.67 \%$, in combined analysis as presented in Table 3. Data indicated that E.C. and germination percent of soybean seed were significantly affected by the different planting dates; that delaying soybean planting date significantly decreased seed E.C. mm, while germination percent was significantly increased over both seasons (combined data).

In this aspect, Green et al. (1965) concluded that soybean seed obtained from later sowing dates, which reached maturity after hot dry weather had ended, generally exhibited higher germination and field emergence than that matured during hot dry weather. The studied soybean genotypes differed significantly in the percentage of seed germination, which Toano recorded the highest value $(90.22 \%)$ overall genotypes, followed by Giza $111(83.56 \%)$ in the combined analysis, while $\mathrm{H} 32$ gave the lowest value $(60.22 \%)$ of this trait over the different planting dates in the combined analysis. On the other hand, data in Table3 show that, Toano recorded the lowest value of E.C. than other genotypes, while $\mathrm{H} 32$ recorded the highest value of this trait across the different planting dates

Data in table 4 show that, soybean seed viability expressed as percentage of seed germination and E.C. 
values were significantly affected by the interaction of planting dates and soybean genotypes over both seasons. The highest germination percentage (96.0) was recorded by Toano in the late planting date (June, 15), while the lowest values $(45.33 \%)$ was recorded by H32 in the early planting date (May, 15). This wide variation could be attributed to the difference in maturity duration of both genotypes, that Toano is a determinate growth type and belong to maturity $\mathrm{V}$, while $\mathrm{H} 32$ is classified as an early maturity group IV genotype.

Table 2. Interaction effect of sowing date and soybean genotypes on maturity date (days), 100-seed weight, and seed yield ton fed $^{-1}$, of soybean genotypes.

\begin{tabular}{|c|c|c|c|c|c|c|c|c|c|c|c|c|c|c|c|}
\hline \multirow{2}{*}{$\begin{array}{l}\text { Characters } \\
\text { genotypes }\end{array}$} & \multicolumn{3}{|c|}{$\begin{array}{l}\text { Days to flowering } \\
\text { (no.) }\end{array}$} & \multicolumn{3}{|c|}{$\begin{array}{c}\text { Days to maturity } \\
\text { (no.) }\end{array}$} & \multicolumn{3}{|c|}{$\begin{array}{l}\text { Reproductive } \\
\text { growth stage (days) }\end{array}$} & \multicolumn{3}{|c|}{ 100-seed yield (gm) } & \multicolumn{3}{|c|}{ Seed yield ton fed $^{-1}$} \\
\hline & D1 & D2 & D3 & D1 & & D3 & D1 & & D3 & D1 & D2 & D3 & D1 & D2 & D3 \\
\hline \multicolumn{16}{|l|}{ Seasons 2013} \\
\hline & 31.3 & 1.3 & 8.0 & 118.7 & 17.0 & 107.0 & 87.4 & 85.7 & 79.0 & 13.14 & 11.37 & 8.51 & 1.637 & 1.417 & 0.950 \\
\hline & 36.0 & 1.3 & 8.0 & 29.0 & & 117.0 & 93.0 & & 89.0 & & & & & & \\
\hline & 38.0 & 33.0 & 30.0 & 129.0 & 127.0 & 117.0 & 91.0 & 94.0 & 87.0 & & & 8.77 & & 1.827 & .063 \\
\hline & 34.0 & 1.0 & 8.0 & 124.0 & 119.0 & 115.0 & 90.0 & 91.0 & 86.0 & & & & & & .013 \\
\hline & & 8.0 & 6.0 & & & & 91.0 & & 86.0 & & & & & & \\
\hline & & 3.0 & & & & & 93.7 & & 91.3 & & & & & & 57 \\
\hline & & 1.0 & & & & & 95.4 & & & & & & & & \\
\hline & & 9.0 & & & & & 96.3 & & 3 & & & & & & \\
\hline & & 1.0 & & 50.0 & & 138.0 & 97.0 & 97 & 90.0 & & & & & & \\
\hline & & 52.0 & & 153.7 & & 141.7 & 98.7 & 99 & 94.7 & & & & & & .843 \\
\hline & & NS & & & & & & 6.55 & & & & & & & \\
\hline \multicolumn{16}{|l|}{ Seasor } \\
\hline & 4.0 & 9.7 & 8.7 & 22.3 & & 07.7 & 88.3 & & 79.1 & & & & & & 967 \\
\hline & 36.0 & 9.7 & 28.7 & & & & 4.3 & & 83 & & & & & & \\
\hline & 39.0 & 31.7 & 30.7 & 31.3 & & & 92.3 & & 83 & & & & & & .311 \\
\hline & 34.0 & 29.7 & 28.7 & 126.7 & & 119.3 & 92.7 & & 90.6 & & & & & & .183 \\
\hline & & 27.0 & & & & & 93.4 & & & & & & & & \\
\hline & & & & & & & 92.0 & & & & & & & & \\
\hline & & & & & & & 4.7 & & & & & & & & \\
\hline & & & & & & & & & & & & & & & \\
\hline & & & & & & & & & 92 & & & & & & \\
\hline & 52.0 & 51.7 & 49.7 & 158.7 & & 142.7 & 106.7 & & 93.0 & & & & 1.600 & & \\
\hline & & NS & & & NS & & & 6.581 & & & 0.703 & & & & \\
\hline \multicolumn{16}{|l|}{$\mathrm{omb}$} \\
\hline & & 30.5 & & & & & 87.8 & & 79. & & & & & & \\
\hline & & 30.5 & & 29.7 & & 114.5 & 93. & & 86 & & & & & & \\
\hline & & 32.2 & 30.4 & 130.2 & & 115.5 & 91.5 & & 85 & & & & & & 1.252 \\
\hline & & 30.4 & & 125.4 & & 117.2 & 91.5 & & 88 & & & & & & 1.098 \\
\hline & & 27.5 & & & & & 92.2 & & & & & & & & 1.148 \\
\hline & & 32.4 & & 131.3 & & & 92.5 & & 93 & & & & & & 1.365 \\
\hline & & 30.4 & & 129.0 & & & 95.1 & & 86 & & & & & & 0.905 \\
\hline & & 8.2 & & 144.2 & & & 94.2 & & 90.9 & & & & & & 1.014 \\
\hline & 52.0 & 50.4 & 47.9 & 150.0 & & 139.0 & 97.5 & & & & & & & 1.344 & 1.034 \\
\hline DR 101 & 53.0 & 51.9 & 48.9 & 156.2 & 152.5 & 142.2 & 102.7 & 100.7 & 94.4 & 18.47 & 18.25 & 14.88 & 1.619 & 1.296 & 0.887 \\
\hline L.S.D. $0.01(\mathrm{a} \times \mathrm{c})$ & & & & & & & & 4.561 & & & & & & 0.224 & \\
\hline
\end{tabular}

Table 3. Some seed quality properties of soybean genotypes as affected by three planting dates.

\begin{tabular}{|c|c|c|c|c|c|c|c|c|c|c|c|c|}
\hline \multirow{2}{*}{$\begin{array}{l}\text { Character } \\
\text { Treatment } \\
\text { planting } \\
\text { date (D) }\end{array}$} & \multicolumn{3}{|c|}{ E.C.mm } & \multicolumn{3}{|c|}{ Germination \% } & \multicolumn{3}{|c|}{ Oil\% } & \multicolumn{3}{|c|}{ Protein \% } \\
\hline & 2013 & 2014 & Comb. & 2013 & 2014 & Comb. & 2013 & 2014 & Comb. & 2013 & 2014 & Comb. \\
\hline D1 & 28.0 & 23.1 & 25.5 & 71.33 & 67.07 & 69.50 & 22.95 & 23.16 & 23.06 & 33.39 & 33.06 & 33.23 \\
\hline D2 & 21.2 & 18.3 & 19.0 & 78.13 & 69.33 & 73.73 & 20.03 & 20.42 & 20.43 & 35.22 & 37.19 & 36.51 \\
\hline D3 & 15.3 & 15.5 & 15.4 & 90.00 & 89.33 & 89.67 & 19.52 & 19.16 & 19.18 & 38.84 & 39.74 & 39.09 \\
\hline L.S.D 0.01 & 0.374 & 0.466 & 0.477 & 5.269 & 3.509 & 2.110 & 0.323 & 0.370 & 0.179 & 1.614 & 1.09 & 0.557 \\
\hline \multicolumn{13}{|c|}{ Genotypes (G) } \\
\hline H 30 & 17.4 & 19.7 & 18.6 & 76.00 & 81.78 & 78.89 & 20.85 & 20.91 & 20.88 & 34.55 & 33.32 & 34.11 \\
\hline H 32 & 20.4 & 21.5 & 20.8 & 62.67 & 57.78 & 60.22 & 20.03 & 19.88 & 19.96 & 33.84 & 32.72 & 33.73 \\
\hline H2 L12 & 21.6 & 20.4 & 21.5 & 75.44 & 67.33 & 71.56 & 20.63 & 20.72 & 20.50 & 33.56 & 32.74 & 32.99 \\
\hline Giza 22 & 20.4 & 17.2 & 18.8 & 83.44 & 82.22 & 83.33 & 20.72 & 20.77 & 20.74 & 37.44 & 38.86 & 38.32 \\
\hline Giza 35 & 31.9 & 23.1 & 27.5 & 75.56 & 64.00 & 69.78 & 21.36 & 21.44 & 21.11 & 34.26 & 35.77 & 35.52 \\
\hline Giza 111 & 18.5 & 17.4 & 17.9 & 87.11 & 80.00 & 83.56 & 20.79 & 21.04 & 20.88 & 36.42 & 39.70 & 38.06 \\
\hline Crawford & 19.4 & 19.0 & 19.2 & 81.33 & 75.11 & 78.22 & 20.40 & 20.41 & 20.41 & 35.18 & 39.30 & 36.91 \\
\hline Toano & 19.7 & 18.7 & 19.7 & 88.89 & 91.56 & 90.22 & 21.68 & 21.84 & 22.50 & 36.34 & 36.79 & 37.23 \\
\hline Holladay & 23.0 & 16.8 & 19.9 & 83.55 & 74.22 & 79.11 & 21.36 & 21.54 & 21.49 & 37.54 & 41.67 & 39.77 \\
\hline DR 101 & 22.7 & 15.5 & 19.1 & 83.55 & 78.45 & 81.00 & 20.51 & 20.54 & 20.53 & 35.96 & 35.86 & 36.24 \\
\hline L.S.D ${ }_{0.01}$ & 1.796 & 0.687 & 0.871 & 3.34 & 4.084 & 2.590 & 0.534 & 0.370 & 0.316 & 0.995 & 0.535 & 0.555 \\
\hline
\end{tabular}


Among all studied genotypes Giza 111, Toano and DR 101 produced viable seeds (more than $80 \%$ germination) when planted took place during the first half of June over both seasons. It was noticed also that, all studied genotypes except Toano produced seeds poor germination in the early planting date, and the earlier genotypes H30, Giza 35, and H32 produced viable seeds (more than $80 \%$ germination) when planted in June, 15 over both seasons.

Table 4. Interaction effect of sowing dates and soybean genotypes on some seed quality properties of soybean genotypes.

\begin{tabular}{|c|c|c|c|c|c|c|c|c|c|c|c|c|}
\hline \multirow{2}{*}{$\begin{array}{l}\text { Characters } \\
\text { Cultivars } \\
\text { Seasons } 2013\end{array}$} & \multicolumn{3}{|c|}{ E.C.mm } & \multicolumn{3}{|c|}{ Germination \% } & \multicolumn{3}{|c|}{ Oil\% } & \multicolumn{3}{|c|}{ Protein \% } \\
\hline & D1 & D2 & D3 & D1 & D2 & D3 & D1 & D2 & D3 & D1 & D2 & D3 \\
\hline $\mathrm{H}_{30}$ & 25.0 & 15.3 & 11.8 & 58.67 & 77.33 & 92.00 & 22.75 & 20.64 & 19.17 & 32.03 & 36.16 & 35.46 \\
\hline $\mathrm{H}_{32}$ & 30.5 & 17.7 & 13.0 & 46.67 & 58.67 & 82.67 & 20.01 & 20.17 & 19.91 & 33.47 & 33.94 & 34.11 \\
\hline $\mathrm{H}_{2} \mathrm{~L}_{12}$ & 26.5 & 21.0 & 17.2 & 69.33 & 64.00 & 93.00 & 21.46 & 21.11 & 19.32 & 28.79 & 39.31 & 32.58 \\
\hline Giza 22 & 27.5 & 21.4 & 12.4 & 78.67 & 81.33 & 93.33 & 22.97 & 19.65 & 19.53 & 34.38 & 37.16 & 40.78 \\
\hline Giza 35 & 33.1 & 38.2 & 24.5 & 64.00 & 80.00 & 82.67 & 22.81 & 20.91 & 20.35 & 32.76 & 34.47 & 35.56 \\
\hline Giza 111 & 21.4 & 19.4 & 14.6 & 78.67 & 92.00 & 90.67 & 22.62 & 18.33 & 21.41 & 31.90 & 32.56 & 44.80 \\
\hline Crawford & 29.0 & 16.8 & 12.5 & 77.33 & 78.67 & 88.00 & 24.16 & 18.79 & 18.26 & 30.55 & 32.64 & 42.34 \\
\hline Toano & 23.2 & 18.9 & 17.1 & 78.67 & 92.00 & 96.00 & 25.04 & 20.65 & 19.35 & 33.46 & 35.56 & 39.99 \\
\hline Holladay & 31.2 & 21.9 & 15.9 & 85.33 & 76.00 & 89.33 & 24.08 & 21.38 & 18.62 & 31.89 & 35.64 & 45.09 \\
\hline DR 101 & 32.6 & 21.1 & 14.3 & 76.00 & 81.33 & 93.33 & 23.59 & 18.69 & 19.25 & 34.80 & 35.24 & 37.83 \\
\hline L.S.D ${ }_{0.01}(\mathrm{dxc})$ & & 3.110 & & & 5.781 & & & 1.018 & & & 1.723 & \\
\hline \multicolumn{13}{|l|}{ Seasons 2014} \\
\hline $\mathrm{H}_{30}$ & 22.8 & 20.8 & 15.6 & 80.00 & 74.67 & 90.67 & 22.74 & 20.44 & 19.54 & 32.36 & 31.36 & 36.25 \\
\hline $\mathrm{H}_{32}$ & 27.9 & 18.9 & 17.7 & 44.00 & 49.33 & 80.00 & 20.24 & 20.04 & 19.36 & 31.11 & 33.13 & 33.93 \\
\hline $\mathrm{H}_{2} \mathrm{~L}_{12}$ & 27.2 & 18.3 & 15.7 & 44.00 & 64.00 & 94.00 & 21.53 & 21.22 & 19.42 & 29.06 & 30.06 & 39.09 \\
\hline Giza 22 & 20.0 & 19.0 & 12.7 & 84.00 & 72.00 & 90.67 & 23.24 & 19.53 & 19.53 & 36.83 & 39.38 & 40.38 \\
\hline Giza 35 & 25.3 & 23.4 & 20.7 & 65.33 & 44.00 & 82.67 & 22.88 & 21.00 & 20.45 & 34.41 & 35.95 & 36.95 \\
\hline Giza 111 & 21.3 & 16.4 & 14.6 & 70.67 & 80.00 & 89.33 & 22.92 & 21.75 & 18.45 & 31.31 & 42.90 & 44.90 \\
\hline Crawford & 27.0 & 17.3 & 12.8 & 77.33 & 60.00 & 88.00 & 24.53 & 18.62 & 18.07 & 30.51 & 42.70 & 44.70 \\
\hline Toano & 24.0 & 16.5 & 15.6 & 90.67 & 88.00 & 96.00 & 25.19 & 20.63 & 19.71 & 35.20 & 36.20 & 38.96 \\
\hline Holladay & 18.2 & 16.6 & 15.5 & 56.00 & 77.33 & 89.33 & 24.52 & 21.53 & 18.58 & 35.87 & 44.07 & 45.07 \\
\hline DR 101 & 17.3 & 15.4 & 13.8 & 58.67 & 84.00 & 92.67 & 23.67 & 19.36 & 18.58 & 34.28 & 36.15 & 37.15 \\
\hline L.S.D ${ }_{0.01}(\mathrm{dxc})$ & & 1.190 & & & 7.074 & & & 0.457 & & & 0.927 & \\
\hline \multicolumn{13}{|l|}{ Comb. } \\
\hline $\mathrm{H}_{30}$ & 16.3 & 23.9 & 15.5 & 69.33 & 76.00 & 91.33 & 22.75 & 20.54 & 19.36 & 32.20 & 34.26 & 35.86 \\
\hline $\mathrm{H}_{32}$ & 20.5 & 24.2 & 17.7 & 45.33 & 54.00 & 81.33 & 20.21 & 19.98 & 19.69 & 33.61 & 33.29 & 34.30 \\
\hline $\mathrm{H}_{2} \mathrm{~L}_{12}$ & 24.1 & 22.4 & 16.4 & 56.67 & 64.00 & 94.00 & 21.50 & 20.64 & 19.37 & 28.93 & 34.19 & 35.84 \\
\hline Giza 22 & 23.6 & 17.2 & 16.9 & 82.67 & 76.66 & 92.00 & 23.11 & 19.59 & 19.53 & 35.61 & 38.77 & 40.58 \\
\hline Giza 35 & 24.7 & 18.8 & 14.6 & 64.67 & 62.00 & 82.67 & 22.85 & 20.96 & 19.53 & 34.09 & 35.71 & 36.76 \\
\hline Giza 111 & 24.9 & 18.2 & 14.1 & 74.67 & 86.00 & 90.00 & 22.77 & 21.48 & 18.39 & 32.11 & 37.23 & 44.85 \\
\hline Crawford & 23.7 & 20.2 & 12.6 & 77.33 & 69.34 & 88.00 & 24.35 & 18.71 & 18.17 & 30.53 & 37.67 & 42.52 \\
\hline Toano & 29.2 & 29.3 & 24.1 & 84.67 & 90.00 & 96.00 & 25.12 & 21.97 & 20.40 & 36.21 & 37.38 & 38.10 \\
\hline Holladay & 21.3 & 16.9 & 16.1 & 71.33 & 76.67 & 89.33 & 24.30 & 21.56 & 18.60 & 33.88 & 40.36 & 45.08 \\
\hline DR 101 & 27.9 & 17.0 & 12.6 & 68.33 & 82.67 & 92.00 & 23.63 & 19.31 & 18.64 & 35.54 & 36.20 & 36.99 \\
\hline L.S.D ${ }_{0.01}(\mathrm{dxc})$ & & 2.313 & & & 4.486 & & & 0.547 & & & 0.961 & \\
\hline
\end{tabular}

These results demonstrated that there was a direct relationship between the varietal differences in seed viability expressed as a percentage of germination and the number of days to maturity for each genotype. It was obvious that the seeds of the long-duration genotypes were more viable than of the short-duration genotypes. Our results agree favorably with other researchers, who found an increase in seed germination as planting is delayed (Green et al. 1965; Tekrony et al., 1984; Avila et al., 2003; El-Borai et al., 2006; Kandil et al., 2013; and Rahman et al., 2013).

Data presented in Table 3 indicated that oil and protein contents of soybean seed were significantly affected by the different planting dates; delaying soybean planting date had significantly decreased seed oil content from 23.06 to $19.18 \%$, while protein content was significantly increased from 33.23 to $39.09 \%$. This result could be explained by the conclusion of Burton (1985) that oil and protein contents of soybean are negatively correlated. The more viable seeds were significantly higher in protein in both seasons.

Seed composition response to planting date differed among genotypes. Average oil content was $20.83 \%$ and ranged from 19.52 to $22.95 \%$ in 2013 . The mean oil content was $20.91 \%$ and ranged from 19.16 to $23.16 \%$ in 2014 Table 3. Soybean oil content was generally highest at the first planting date in both seasons and decreased as planting was delayed. In both seasons oil content of Toano determinate genotype responded more to planting date and had the highest oil content $(22.50 \%)$ over all genotypes followed by Holladay as presented in Table 3. By comparison, H32, and Crawford consistently had the lowest oil contents and were relatively insensitive to planting date. Data presented in Table 4 show clearly that In the combined analysis, Toano had high oil contents across the different planting dates, whereas; Crawford, and Giza 22 indeterminate genotypes had high oil contents at the first planting date and significant decreased in the 
second and third planting dates, with no significant difference in oil contents among both planting dates. Across planting dates and genotypes oil content was greater in 2014 than 2013.

In 2013 the mean protein content increased from 33.23 to $39.09 \%$ due to delaying planting date, whereas in 2014 the mean protein content increased from 33.06 to $39.74 \%$ as presented in Table 3., Holladay and Giza 22 had the highest protein content (39.77 and 38.32\%), respectively; while $\mathrm{H} 32$ had the lowest protein content (33.35\%). Data presented in Table 4 show clearly that protein content of most studied soybean genotypes was significantly increased with delaying planting date except H32, Giza 35, Toano, and DR 101, which showed slight increases in this trait with delaying planting date

Our results agree favorably with other researchers, who show a decrease in oil content and a general increase in protein content as planting is delayed (Bastidas et al., 2008; Kane et al., 1997; and Robinson et al., 2009). They indicated that the differences in the environment, mainly temperature, cause changes in seed composition.

\section{REFERENCES}

A. O. A. C., (1990). Official methods of analysis. The Association of Official Analytical Chemists (15th Edition, Published by Association of Official Analytical Chemists, Arrington, Virginia, USA.)

Amir, Z. K., H. Khan, A. Ghoneim, R. Khan, and A. Ebid, (2007). Seed quality and vigor of soybean as influenced by planting date, density and cultivar under temperate environment. International J. of Agric. Res. 2(4): 386-376.

Andrade, F.H. (1995). Analysis of growth and yield of maize, sunflower and soybean grown at Balcarce, Argentina. Field Crop. Res. 41:1-12.

Avila, M. R., A. de L. BracciniI; I. de S. Motta; C. A. Scapim; M. d. C. L. Braccini, (2003). Sowing seasons and quality of soybean seeds. Sci. agric.,60 (2): 245-252.

Ball, R.A., L.C. Purcell, and E.D. Vories. (2000). Shortseason soybean yield compensation in response to population and water regime. Crop Sci. 40:1070-1078.

Bastidas, A.M., T.D. Setiyono, A. Dobermann, K.G. Cassman, R.W. Elmore, G.L. Graef, and J.E. Specht. (2008). Soybean sowing date: The vegetative, reproductive, and agronomic impacts. Crop Sci. 48:727-740.

Burton, J.W. (1985). Breeding soybean for improved protein quantity and quality. In: World Soybean Research Conference, III: Proceedings, Ed. R Shibles, Boulder,CO:Westview Press,p. 361-367.

Chen, G., and P. Wiatrak. (2010). Soybean development and yield are influenced by planting date and environmental conditions in the Southeastern Coastal Plain, United States. Agron. J. 102:17311737.
Cooper, R.L., (2003). A delayed flowering barrier to higher soybean yields. Field Crops Res.82:27-35.

David A. M., B. J. Haverkampb, R. G. Laurenzc, J. M. Orlowskid, E. W. Wilsone, S. N. Casteelf, C. D. Leeg, S. L. Naevee, E. D. Nafzigerh, K. L. Roozeboomb, W. J. Rossi, K. D. Thelenc and S. P. Conleya., (2016). Characterizing Genotype $\times$ Management Interactions on Soybean Seed Yield. Crop Sci., 56 (2): 786-796.

De Bruin J.L., and P. Pedersen (2008). Soybean seed yield response to planting date and seeding rate in the Upper Midwest. Agron. J. 100:696-703.

Duncan, D.B. (1955). Multiple ranges and multiple F test. Biometrics, 11:1-42.

Egli D.B., and P.L. Cornelius (2009). A regional analysis of the response of soybean yield to planting date. Agron. J. 101:330-335.

Egli, D.B., and W.P. Bruening. (2000). Potential of early-maturing soybean cultivars in late plantings. Agron. J. 92:532-537.

El-Borai, M.A., M.I. El-Emery, Soaad A. El-Sayed, and Ola A.M. El-Galaly (2006). Optimal sowing date for producing high quality soybean seed in Egypt. First Field Crops Conference 22-24, August; 372-380.

Garica, A., (1994). Planting practices and stand establishment. Tropical soybean improvement and production. Food and agriculture organization of the united nations. 115-116.

Green, D.E.; E.L. Pinnell; L.E. Gavanah and L.F. Williams (1965). Effect of planting date and maturity date on soybean seed quality. Agron. J. 57:165-168.

Heatherly, L.G. 2005. Soybean development in the midsouthern USA related to date of planting and maturity classification. Crop Manage. :doi: 10.1094/CM-2005-0421-01-RS.

ISTA. (1999). International rules for seed testing, 1999. Supplement to Seed Science and Technology, 27: 27-32.

Jason L. De Bruin, and Palle Pedersen, (2008). Soybean Seed Yield Response to Planting Date and Seeding Rate in the Upper Midwest. Agron. J. 100(3): 696-703.

Jeffery D. R., K. Hinson, J. E. B. Mankono and M. F. Malo.(1996). Genetic Control of a LongJuvenile Trait in Soybean. Crop Sci. 35 ( 4): 1001-1006

Kandil A.A., A.E. Sharief, A.R. Morsy and El-Sayed, A.I. Manar, (2013). Influence of planting date on some genotypes of soybean growth, yield, and grain quality. J. of Biological Sci., 13(3), 146151.

Kane, M.V., C.C. Steele, L.J. Grabau, C.T. MacKown, and D.F. Hildebrand. (1997). Early-maturing soybean cropping system .3. Protein and oil contents and oil composition. Agron. J. 89:464469. 
Kumar, V., A. Rani, V. Pandey, P. Mande, and G.S. Chauhan, (2006). Compositional traits of soybean seeds as influenced by planting date in India. Exp. Agric. 42:19-28.

Muhammad, A., S.K. Khalil, K.B. Marwat, A.Z. Khan, I.H. Khalil, Amanullah, and S.Arifullah. (2009). Nutritional quality and production of soybean land races and improved varieties as affected by planting dates. Pak. J. Bot. 41:683-689.

Pedersen, P., and J.G. Lauer. (2003). Soybean agronomic response to management systems in the upper Midwest. Agron. J. 95:1146-1151.

Pedersen, P., and J.G. Lauer. (2004). Soybean growth and development response to rotation sequence and tillage system. Agron. J. 96:1005-1012.

Rahman, M. M., M. M. Rahman, M. M. Hossain, (2013). Effect of sowing date on germination and vigor of soybean (Glycine max (L.) Merr) seeds. The Agriculturists 11(1): 67-75.

Robinson, A. P., Shawn P. Conley, Jeffrey J. Volenec, and Judith B. Santini, (2009). Analysis of high yielding, early-planted soybean in Indiana. Agron. J., 101(1), 131-139.

Salmeron, M., Gbur, E.E., Bourland, F.M., Buehring, N.W., Earnest, L., Fritschi, F.B., Golden, B.R., Hathcoat, D., Lofton, J., Miller, T.D., Neely, C., Shannon, G., Udeigwe, T.K., Verbree, E.D. Vories, W.J. Wiebold, and L.C. Purcell. (2014). Soybean maturity group choices for early and late planting in the Mid-South. Agron. J. 106:18931901.

Salmeróna,M., Edward E. Gburb, Fred M. Bourlandc, Normie W. Buehringd, Larry Earneste, Felix B. Fritschif,Bobby R. Goldeng, Daniel Hathcoati, Josh Loftonh, Angela Thompson Mc Clurem, TravisD. Milleri, Clark Neelyi, Grover Shannonj, Theophilus K. Udeigwel, David A. Verbreem,
Earl D. Voriesk, William J. Wieboldf and Larry C. Purcell, (2016). Yield Response to Planting Date Among Soybean Maturity Groups for Irrigated Production in the US Mid-South Crop Sci., 56(1): 1-13.

Scott C. Rowntreea, Justin J. Suhreb, Nicholas H. Weidenbennerc, Eric W. Wilsond, Vince M. Davisa, Seth L. Naevec, Shaun N. Casteeld, Brian W. Diersb, Paul D. Eskere, James E. Spechtf and Shawn P. Conley. (2013). Genetic Gain $\times$ Management Interactions in Soybean: I. Planting Date. Crop Sci., 53(): 1128-1138.

Snedecor, G. W and W. G. Cochran (1967). Statistical Method 6th ed., Lowa State Univ. Press, Amer., Lawa, USA.

Tekrony, D.M.; D.B. Egli; John Balles; L. Tomes and R.E. Stuckey, (1984). Effect of date of harvest maturity on soybean seed quality and Phomopsis $s p$ seed infection. Crop Sci. 24:189-193.

Tremblay, G.J., J.M. Beausoleil, P. Filion, and M. Saulnier, (2006). Response of three soybean cultivars to seeding date. Can. J. Plant Sci. 86:1071-1078.

Valéria C. P., L. A.Almeida and R. A. S. Kiihl (2002).Inheritance of a long juvenile period under short-day conditions in soybean. Genetics and Molecular Biology, 25, (4): 463-469.

Wilcox, J.R., and E.M. Frankenberger, (1987). Indeterminate and determinate soybean responses to planting date. Agron. J. 79:1074-1078.

\section{تأثير محصول البذور وكذلك جودة البذور لبعض التراكيب الوراثية لفول الصويا تحت تأثير مواعيد الزراعة المختلفة

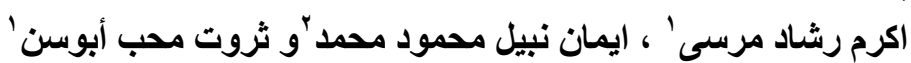

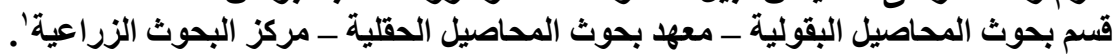

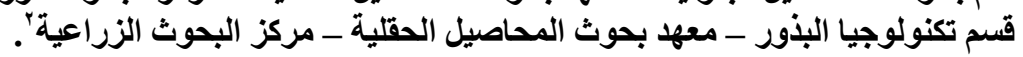

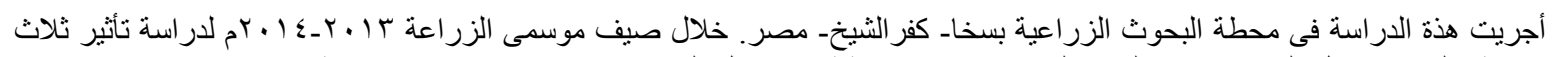

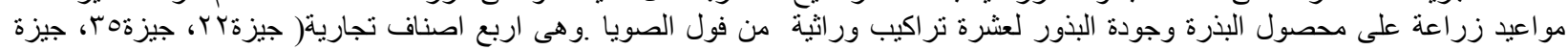

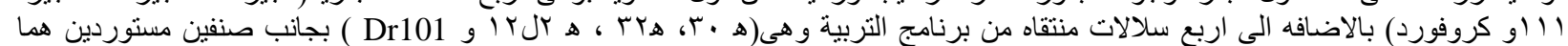

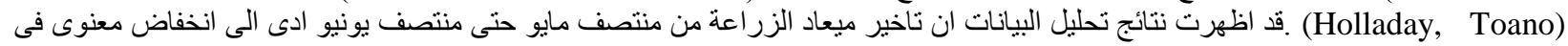

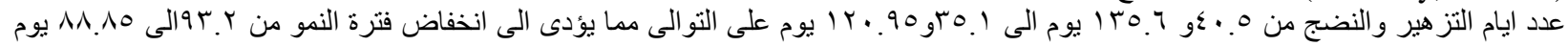

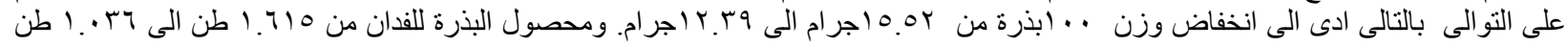

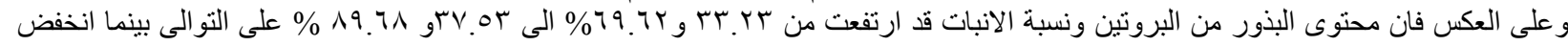

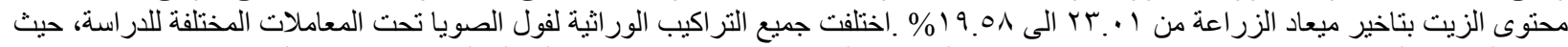

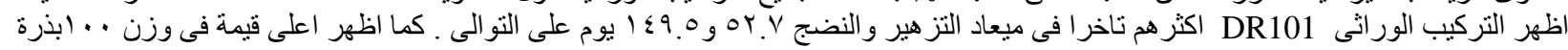

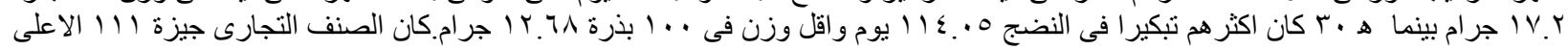

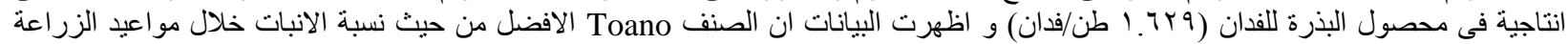

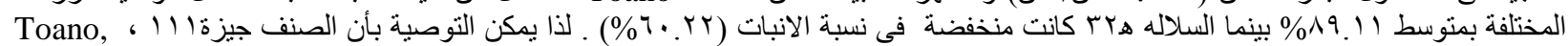

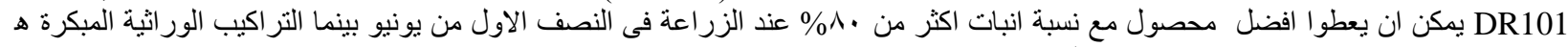

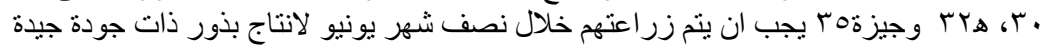

